\title{
Histomorphological mimickers of benign prostatic lesions with prostatic adenocarcinoma
}

\author{
Priyanka Sangappa Murgod ${ }^{1}$, Preeti Rajeev Doshi ${ }^{2}$, Amit Ravindra Nisal ${ }^{2}$, \\ Ravindra Chandrashekhar Nimbargi ${ }^{2}$
}

${ }^{1}$ Department of Pathology; Bharati Vidyapeeth (DU) medical college and Hospital, Pune, India

${ }^{2}$ Department of Pathology; Maharashtra Institute of Medical Education and Research Medical College, Pune, India

\section{Keywords: \\ Gleason; \\ Hyperplasia; \\ Prostate-specific antigen; \\ Prostatic adenocarcinoma;}

\begin{abstract}
Background: The prostate is a walnut-sized organ that surrounds the urethra. More than $99 \%$ of prostate cancers are prostatic adenocarcinoma. It is the second most commonly occurring cancer in men and the fourth most commonly occurring cancer in India and all over the world. Numerous lesion of the prostate are very similar to prostate cancer, hence awareness is very important. This study aimed to determine the histopathological features of prostate adenocarcinoma and its common mimickers.
\end{abstract}

Materials and Methods: A retrospective study of histopathological features of radical prostatectomy and transurethral resection of the prostate specimens, sent to the department of pathology for a period of one year. A brief clinical history and serum prostate-specific antigen levels were noted.

Results: The surgical specimens of 303 cases of prostatic diseases were studied. Benign prostatic hyperplasia was the most frequent diagnosis in 192 patients followed by Prostate adenocarcinoma seen in 80 patients. Prostatic intraepithelial neoplasia formed the predominant mimicker (5.9\%), followed by basal cell hyperplasia (3.0\%). Serum prostate-specific antigen was seen in the range of $1.73-100 \mathrm{ng} / \mathrm{ml}$ in the cases of adenocarcinoma. In the mimics, prostate-specific antigen was in the range of $1.2-18 \mathrm{ng} / \mathrm{ml}$.

Conclusions: Biopsy remains a gold standard for the diagnosis of adenocarcinoma and its mimickers. The lesions in this study were diagnosed on hematoxylin and eosin staining.

\section{Correspondence:}

Dr. Doshi Preeti Rajeev, MD

Associate Professor, Bharati Vidyapeeth (DU) medical college and

Hospital, Pune, India

ORCID ID:0000-0002-6454-5435

Email:prdoshi22@gmail.com

Received : May $19^{\text {th }} 2020$; Accepted : December $20^{\text {th }} 2020$

Citation: Murgod PS, Doshi PR, Nisal AR, Nimbargi RC. Histomorphological mimickers of benign prostatic lesions with prostatic adenocarcinoma. J Pathol Nep 2021;11:1859-63. DOI: 10.3126/jpn. v10i2.29009

Copyright: This is an open-access article distributed under the terms of the Creative Commons Attribution 4.0 International License, which permits unrestricted use, distribution, and reproduction in any medium, provided the original author and source are credited.

\section{INTRODUCTION}

Prostate adenocarcinoma (PC) is the second most commonly occurring cancer in men and the fourth most commonly occurring cancer in India and all over the world. It is the most common cancer in men in Europe, North America, and parts of Africa. ${ }^{1}$ In India, it is among the top 10 leading sites of malignancy according to the PopulationBased Cancer Registries constituting around 5\% of all cancers. ${ }^{2,3}$ Sometimes the diagnosis becomes a challenge because numerous benign prostatic and nonprostatic lesions and normal structures can be very similar to prostatic adenocarcinoma. Therefore, knowledge about the 
mimickers of PC is important to avoid misdiagnosis. This study aimed to determine the histopathological features of prostate adenocarcinoma and its common mimickers.

\section{MATERIALS AND METHODS}

A retrospective study of all the radical prostatectomy and transurethral resection of the prostate (TURP) specimens received in the pathology department of a Bharati Vidyapeeth (DU) medical college was done for 1 year. A brief clinical history was noted along with serum prostatespecific antigen (PSA) levels. The specimens were received and fixed in $10 \%$ neutral buffered formalin and routine paraffin processing was done, followed by hematoxylin and eosin ( $\mathrm{H}$ and $\mathrm{E})$ staining of sections. All the slides were examined under a microscope, and each case was studied concerning age, clinical presentation, PSA levels, and microscopic picture, based on which a final diagnosis was given. The cases were classified into three groups adenocarcinoma, benign prostate hyperplasia (BPH), and mimickers of PC. Gleason's grading system was used for grading the carcinomas. Immunohistochemistry (IHC) was not done as the study was taken up as a retrospective study.

\section{RESULTS}

This study comprises a total of 303 cases of which 80 cases (26.4\%) were of adenocarcinoma and 31 cases (10.2\%) were mimickers (Table 1). Serum PSA was markedly elevated in prostatic adenocarcinoma. There was a wide range of PSA values among the patients with BPH with or without prostatitis.

The prostatic intraepithelial neoplasm was the most common mimicker which was seen in 18 cases $(5.9 \%)$ followed by basal cell hyperplasia seen in 9 cases (3\%) (Table 2).

Table 1: Histopathological diagnosis of a prostatic lesion with age and PSA levels.

\begin{tabular}{lccc}
\hline Histopathological Diagnosis & No of Cases & Age (years) & PSA Levels(ng/dl) \\
BPH & $95(31.35 \%)$ & $28-92$ & $0.1-67$ \\
\hline BPH With Prostatitis & $97(32.01 \%)$ & $49-96$ & $0.2-50.24$ \\
\hline Mimickers of prostatic lesions & $31(10.23 \%)$ & $58-77$ & $6.1-18$ \\
\hline Prostatic Adenocarcinoma & $80(26.40 \%)$ & $49-91$ & $12-100$ \\
\hline
\end{tabular}

Table 2: Mimikers of prostatic adenocarcinoma

\begin{tabular}{lc}
\hline $\begin{array}{l}\text { Mimickers of Prostatic } \\
\text { adenocarcinoma }\end{array}$ & No. of cases (\%) \\
\hline Basal cell hyperplasia & $09(3 \%)$ \\
\hline Prostatic atrophy & $00(0.0 \%)$ \\
\hline Clear cell cribriform hyperplasia & $01(0.3 \%)$ \\
\hline Atypical adenomatous hyperplasia & $03(1.0 \%)$ \\
\hline Prostatic intraepithelial neoplasia & $18(5.9 \%)$ \\
\hline Total & $\mathbf{3 1}(\mathbf{1 0 . 2 3 \% )}$ \\
\hline
\end{tabular}

Table 3: Prostatic adenocarcinoma comparison with age and PSA Levels

\begin{tabular}{lcc}
\hline Age (Years) & No of Adenocarcinoma Cases & PSA Levels (ng/dl) \\
\hline $51-60$ & 07 & $69-100$ \\
\hline $61-70$ & 27 & $18-98$ \\
\hline $71-80$ & 34 & $14-100$ \\
\hline $81-90$ & 11 & $12-100$ \\
\hline $91-100$ & 01 & 13 \\
\hline Total & $\mathbf{8 0}$ & \\
\hline
\end{tabular}

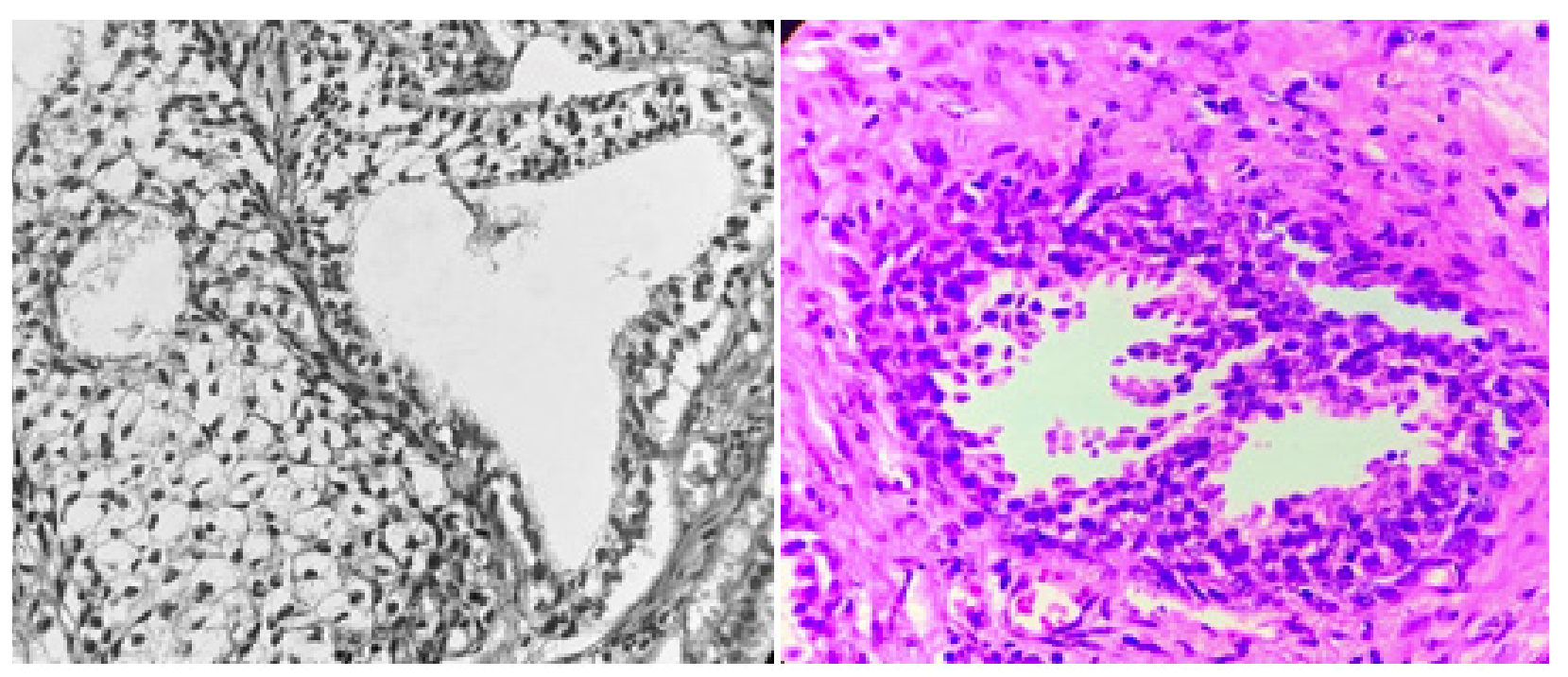

Figure 1: A) Photomicrograph showing basal cell hyperplasia (HE stain, X40). B) Photmicrograph showing low grade PIN (HE stain, X40). 
Granulomatous prostatitis (02 cases) which were included in BPH with prostatitis. The mimickers were seen focally in the biopsy and specimen. The clinical features included obstructive urinary symptoms, frequency, urgency, nocturia, and dysuria in all the cases. In addition, hematuria was seen in PC as a predominant clinical feature. Serum PSA was seen in the range of 12 to $>100 \mathrm{ng} / \mathrm{ml}$ in the cases of PC (Table 1 and 3).

The mimickers, PSA was in the range of 1.2 to $18 \mathrm{ng} / \mathrm{ml}$. PC grading was done as per Gleason criteria in all 80 cases and the maximum cases were seen with group grade 2 followed by group grade 5 . The commonest common pattern in our study was patterns 2 and 3 . The prominent features noted were tumor cells with nuclear enlargement and hyperchromasia and prominent nucleoli at places and these tumour cells were seen infiltrating the stroma. The absence of basal cell layer was seen in the majority of cases and the presence of perineural invasion in few cases of PC. Maximum numbers of mimickers are seen in the age group of 61-70 years of age, followed by 51-60 years and 71-80 years ( 05 cases each).

Besides the above histopathological lesions, a number of other mimickers such as Cowper's gland, seminal vesicle, mesonephric glands, inflammatory processes including granulomatous prostatitis, xanthogranulomatous prostatitis, and malakoplakia, sclerosing adenosis, nephrogenic adenoma, and few others can be confused with adenocarcinoma. However, we did not find any of the above lesions in our study. Biopsy remains a gold standard for the diagnosis of PC. All the lesions in the above study were diagnosed on routine $\mathrm{H}$ and $\mathrm{E}$ staining (fig. $1 \mathrm{~A}$ and $\mathrm{B}$ ).

\section{DISCUSSION}

Many normal and pathologic lesions in the genitourinary system can resemble neoplastic processes histologically. This study focuses on those histological mimickers as it is the differential diagnosis of prostatic adenocarcinoma. There are many lesion that can mimic prostatic adenocarcinoma histologically. Such lesions have been broadly divided into benign prostate hyperplasia, prostatic adenocarcinoma, and mimickers. The benign entities most often misdiagnosed as prostatic adenocarcinoma are atrophy, crowded benign glands, atypical adenomatous hyperplasia, and basal cell hyperplasia. In Epstein JI et al review of 535 consecutive needle biopsies, $7(1.3 \%)$ were classified as false-positives. ${ }^{4}$ These 07 cases comprised 05 cases of atypical adenomatous hyperplasia and 02 cases of atrophy.

Herawi $\mathrm{M}$, on needle core biopsy tissue, found partial atrophy and crowded benign glands to be the most frequent benign mimickers of prostatic carcinoma. ${ }^{5}$ In Bostwick DG et al study that focused on TURP chips, cases misinterpreted as adenocarcinoma included atypical adenomatous hyperplasia ( $26 \%$ of the false-positive cases), basal cell hyperplasia (26\%), atrophy (16\%), sclerosing adenosis $(10 \%)$, high-grade prostatic intraepithelial neoplasia $(10 \%)$, xanthogranulomatous prostatitis $(6 \%)$, florid cribriform hyperplasia (3\%), and post atrophic hyperplasia $(3 \%){ }^{6}$ Atrophy is a common age-related process that represents one of the benign lesions most frequently misdiagnosed as carcinoma. But in the present study, we did not come across prostatic atrophy cases as compared to the study done by Bostwick DG et al and Herawi M. ${ }^{5,6}$

The occurrence of PIN in specimens is reported to be relative $2 \%-4 \%{ }^{7}$ We noted an incidence of $18 \%$ cases of PIN in our study and was the most common mimicker. It can be confused with PC because of atypical epithelial cell proliferation with crowded, pseudostratified cells and cytologic atypia in the form of nuclear irregularity, nucleomegaly, hyperchromasia, and prominent nucleoli. ${ }^{8,9}$ The presence of basal cells can help differentiate PIN from prostatic adenocarcinoma in which the basal cells are absent.

Basal cell hyperplasia $(\mathrm{BCH})$ is classically seen in the transition zone but can also occur in the peripheral zone.10 It is characterized by two or more layers of basal cells with a range of growth patterns, including acinar, cribriform/ pseudo cribriform, and solid patterns ${ }^{11-14}$ or mixtures of these patterns. $\mathrm{BCH}$ occurs in about $23 \%$ of whole prostatic tissues. It can occur in the background of inflammation and after radiation or hormonal therapy ${ }^{15}$ It is one of the entities in the nonneoplastic group, accounting for 3\% of the mimickers while a study done by Mahapatra QS et al accounted for $26 \%$ of $\mathrm{BCH}$ which was the most common entity found in their study. ${ }^{16}$

Atypical adenomatous hyperplasia is another common mimicker of prostatic adenocarcinoma on both needle biopsy and transurethral resection specimens, the incidence varies from 1.5 to $19.6 \% .^{17,18,19,20}$ In our study it was found to be $1 \%$ which correlates with the majority of the studies. Histologically, it is characterized by a nodular proliferation of closely packed, small glands that often merge with larger, more complex glands. Uncommonly, the small acini exhibit a more extensive, crowded, and nonlobular distribution. ${ }^{21,22}$

Cribriform Hyperplasia lesion is usually seen in the transition zone as part of benign nodular epithelial hyperplasia. ${ }^{23}$ It is characterized by a complex cribriform proliferation composed of pale/clear cells. These cells are cuboidal to low columnar, lack cytologic atypia, and are surrounded by basal cells. The latter two features serve to distinguish this pattern of hyperplasia from Gleason grade 4 cribriform adenocarcinoma. Our study accounted for $0.3 \%$ of cribriform hyperplasia among the mimicker as compared Mahapatra QS et al accounted for $4.0 \% .{ }^{16}$

Granulomatous Prostatitis is characterized histologically 
by a granulomatous inflammatory infiltrate that is usually noncaseating and often includes giant cells. The problem with granulomatous prostatitis is that the sheets of epithelioid (or foamy) macrophages, as well as scattered epithelial cells from remnants of ruptured prostatic ducts and acini, may all be confused with high-grade (Gleason grade 5) adenocarcinoma ${ }^{24,25}$ This study found 02 cases of granulomatous prostatitis which were included in BPH with prostatitis.

\section{CONCLUSIONS}

Biopsy remains a gold standard for diagnosis of PC and can be diagnosed on routine hematoxylin\& eosin stain. The knowledge about the mimickers is very important and these mimickers should be differentiated from prostatic adenocarcinoma.

\section{Conflict of Interest: None}

\section{REFERENCES}

1. Pakzad R, Mohammadian-Hafshejani A , Ghoncheh M, Pakzad I, Salehiniya H. The incidence and mortality of prostate cancer and its relationship withdevelopment in Asia. Prostate Int 2015; 3:135-40. Crossref

2. Jain S, Saxena S, Kumar A. Epidemiology of prostate cancer in India. Meta Gene 2014; 2:596-605. Crossref

3. Yadav M, Desai H, Goswani H. Study of various histopathological patterns in prostate biopsy. Int J Curr Res Rev 2017; 9:58-63. Crossref

4. Epstein JI, Walsh PC, Sanfilippo F. Clinical and cost impact of second opinion pathology. Review of prostate biopsies prior to radical prostatectomy. Am J SurgPathol. 1996;20(7):851-7. Crossref

5. Herawi M, Parwani AV, Irie J, Epstein JI. Small glandular proliferations on needle biopsies: most common benign mimickers of prostatic adenocarcinoma sent in for expert second opinion. Am J SurgPathol. 2005;29(7):874-80. Crossref

6. Bostwick DG, Cheng L. Overdiagnosis of prostatic adenocarcinoma. SeminUrolOncol. 1999;17(4):199_ 205.

7. Silverio FD, Gentile V, Matteis AD, Mariotti G, Giuseppe V, Luigi PA, et al. Distribution of inflammation, pre-malignant lesions, incidental carcinoma in histologically confirmed benign prostatic hyperplasia: Retrospective analysis. EuUrol 2003;43:164-75. Crossref
8. Humphrey PA. Disease of the prostate. In: Wick MR, LiVolsi VA, Pfeifer JD, Stelow EB and Wakely PE, editors. Silverberg's Principles \& Practice of Surgical Pathology \& Cytopathology 5th edition. Cambridge University Press; 2015. P. 2500.

9. Zynger DL, Yang X. High-grade prostatic intraepithelial neoplasia of Theprecusor lesion of prostate cancer. Int $\mathrm{J}$ ClinExpPathol2009;2:327-38.

10. Thorson P, Swanson PE, Vollmer RT, Humphrey PA. Basal cell hyperplasia in the peripheral zone of the prostate. Mod Pathol. 2003;16(6):598-606. Crossref

11. Grignon DJ, Ro JY, Ordonez NG, Ayala AG, Cleary KR. Basal cell hyperplasia, adenoid basal cell tumor, and adenoid cystic carcinoma of the prostate gland: an immunohistochemical study. Hum Pathol. 1988;19(12):1425-33.

12. Rioux-Leclercq NC, Epstein JI. Unusual morphologic patterns of basal cell hyperplasia of the prostate. Am J SurgPathol. 2002;26(2):237-43. Crossref

13. Hosler GA, Epstein JI. Basal cell hyperplasia: an unusual diagnostic dilemma on prostate needle biopsies. Hum Pathol. 2005;36(5):480-5. Crossref

14. Ali TZ, Epstein JI. Basal cell carcinoma of the prostate: a clinicopathologic study of 29 cases. Am J SurgPathol. 2007;31(5):697-705. Crossref

15. Thorson P, Swanson PE, Vollmer RT, Humphrey PA. Basal cell hyperplasia in the peripheral zone of the prostate. Mod Pathol 2003;16:598-606.

16. Mahapatra QS, Mohanty P, Nanda A, Mohanty L. Histomorphological study of prostatic adenocarcinoma and its mimics. Indian Journal of Pathology and Microbiology. 2019 Apr 1;62(2):251. Crossref

17. Bostwick DG, Srigley J, Grignon D et al. Atypical adenomatous hyperplasia of the prostate: morphologic criteria for its distinction from welldifferentiated carcinoma. Hum Pathol. 1993;24(8):819-32. Crossref

18. Gaudin PB, Epstein JI. Adenosis of the prostate: histologic features in transurethral resection specimens. Am J SurgPathol. 1994;18(9):863-70.

19. Gaudin PB, Epstein JI. Adenosis of the prostate: histologic features in needle biopsy specimens. Am J SurgPathol. 1995;19(7):737-47. Crossref

20. Xu Y, Wang $\mathrm{Y}$, Zhou R, Li H, Cheng H, Wang Z, Zhang J. The benign mimickers of prostatic acinar 
adenocarcinoma. Chin J Cancer Res 2016;28:72-9. $\underline{\text { Crossref }}$

21. Lotan TL, Epstein JI. Diffuse adenosis of the peripheral zone in prostate needle biopsy and prostatectomy specimens. Am J SurgPathol. 2008;32(9):1360- 6 . $\underline{\text { Crossref }}$

22. Devaraj LT, Bostwick DG. Atypical basal cell hyperplasia of the prostate: immunophenotypic profile and proposed classification of basal cell proliferations. Am J SurgPathol. 1993;17(7):645-59. Crossref
23. Frauenhoffer EE, Ro JY, el-Naggar AK, Ordonez NG, Ayala AG. Clear cell cribriform hyperplasia of the prostate. Immunohistochemical and DNA flow cytometric study. Am J ClinPathol. 1991;95(4):44653. $\underline{\text { Crossref }}$

24. Stillwell TJ, Engen DE, Farrow GM. The clinical spectrum of granulomatous prostatitis: a report of 200 cases. J Urol. 1987;138(2):320-3. Crossref

25. Speights VO, Jr., Brawn PN. Serum prostate specific antigen levels in nonspecific granulomatous prostatitis. Br J Urol. 1996;77(3):408-10. Crossref 